\title{
MISKONSEPSI DALAM MATERI IPA SEKOLAH DASAR
}

\author{
Dek Ngurah Laba Laksana \\ Program Studi Pendidikan Guru Sekolah Dasar, \\ STKIP Citra Bakti, Indonesia
}

Email: laba.laksana@gmail.com

\begin{abstract}
Abstrak
Penelitian ini bertujuan untuk mendeskripsikan miskonsepsi yang terjadi pada calon guru dalam materi IPA di sekolah dasar. Penelitian ini menggunakan pendekatan kualitatif untuk memaparkan lebih dalam mengenai jenis miskonsepsi yang terjadi. Subjek dalam penelitian ini adalah calon guru SD. Jumlah subjek yang dijadikan responden adalah 64 orang, yang terdiri dari 44 orang calon guru perempuan dan 20 orang laki-laki. Hasil penelitian yang diperoleh adalah sebagai berikut. (1) terjadi miskonsepsi dalam berbagai konsep IPA di sekolah dasar, (2) konsep-konsep yang dominan mengalami miskonsepsi dengan persentase lebih dari $60 \%$ adalah (a) konsep zat-zat yang diperlukan dalam proses fotosintesis tumbuhan hijau, b) konsep fotosintesis membutuhkan cahaya, 3) konsep massa jenis zat, dan 4) konsep gerak jatuh bebas.
\end{abstract}

Kata kunci: Miskonsepsi, IPA SD

\begin{abstract}
This study aimed to describe the misconception that occurs in the material science teachers in primary schools. This study used a qualitative approach to explain more about the kinds of misconceptions that occur. Subjects in this study were elementary school pre-service teacher. The number of subjects who used the respondents is 64 people, consisting of 44 female teachers and 20 men. The results obtained are as follows. (1) occurs misconceptions about the various concepts of science in elementary school, (2) the concepts of the dominant experience of misconceptions with a percentage of more than $60 \%$ is (a) the concept of substances that are required in the process of photosynthesis of green plants, b) the concept of photosynthesis requires light, 3) the concept of density of matter, and 4) the concept of motion.
\end{abstract}

Keywords: Misconception, Science Concept at Elementary School

\section{PENDAHULUAN}

Penelitian-penelitian inovatif dalam bidang pendidikan banyak dilakukan beberapa tahun terakhir. Penelitian ini mengkaji penerapan pembelajaran inovatif untuk membantu siswa memahami konsepkonsep dengan menghubungkan antara konten yang dipelajari dengan kehidupan nyata siswa (Seraphin, dkk., 2012). Dasar penelitian ini dilatarbelakangi oleh pembelajaran konvensional yang dilakukan oleh guru terbukti gagal mengembangkan daya nalar siswa (Degeng, 2013). Hal ini dapat dilihat dari ketidakmampuan siswa untuk memecahkan masalah-masalah nyata yang dihadapi dalam kehidupannya (Cakir, 2008). Pembelajaran konvensional ini lebih banyak memberikan teori-teori yang tidak mengakar pada dunia nyata siswa. Pembelajaran tersebut hanya menuangkan pengetahuan sebanyak-banyaknya ke dalam kepala siswa (Reigeluth \& CarrCheliman, 2009).

Sementara itu, Gagne (1985) mengemukakan bahwa siswa hadir ke kelas umumnya tidak dengan kepala kosong, melainkan mereka sudah membawa sejumlah pengalaman-pengalaman atau ide-ide yang dibentuk sebelumnya ketika 
mereka berinteraksi dengan lingkungannya. Artinya bahwa sebelum pembelajaran berlangsung sesungguhnya siswa telah membawa sejumlah ide-ide atau gagasan yang sudah didapatkan sebelumnya. Menurut Longfield, (2009), gagasangagasan yang telah dimiliki oleh siswa sebelumnya inilah yang disebut prakonsepsi atau konsepsi alternatif. Prakonsepsi ini juga sering muncul sebagai miskonsepsi.

Fowler dan Jaoude

menyatakan bahwa yang dimaksud dengan miskonsepsi adalah pengertian tentang suatu konsep yang tidak tepat, salah dalam menggunakan konsep nama, salah dalam mengklasifikasikan contoh-contoh konsep, keraguan terhadap konsep-konsep yang berbeda, tidak tepat dalam menghubungkan berbagai macam konsep dalam susunan hierarkinya atau pembuatan generalisasi suatu konsep yang berlebihan atau kurang jelas. Menurut Amien (1990) miskonsepsi dapat pula terjadi karena adanya gagasan atau ide yang didasarkan pada pengalaman yang tidak relevan. Jika miskonsepsi terjadi pada peserta didik cenderung menetap dan sulit untuk diubah serta akan berpengaruh pada proses belajar mengajar berikutnya.

$$
\text { Miskonsepsi dalam IPA dan }
$$

Matematika (Akbas \& Gencturk, 2011; Hershey, 2004; Howe, 1993; Novak, 1987; Timur, 2012) ditemukan bahwa miskonsepsi terhadap konsep IPA banyak terjadi pada murid di berbagai negara mulai dari murid tingkat Sekolah Dasar (SD) sampai dengan mahasiswa di Perguruan Tinggi. Miskonsepsi yang ditemukan hampir disemua materi IPA dari gaya dan gerak, bumi dan antariksa, tumbuhan dan makhluk hidup. Untuk itu perlu dilakukan kajian lebih mendalam mengenai miskonspsi yang terjadi untuk kultur pembelajaran dengan lingkungan belajar yang berbeda.

Beberapa survei dan penelitian yang ada, tampak komponen guru sebagai pengajar menjadi titik awal terjadinya miskonsepsi pada siswa. Hal ini ditunjukkan dari fakta bahwa pemahaman guru terhadap materi IPA masih rendah (Laksana, 2014). Suryanto (1997) menyatakan bahwa ratarata guru SD hanya mampu menguasai $45 \%$ dari keseluruhan materi yang seharusnya mereka kuasai. Hal yang sama juga ditemukan terhadap guru IPA SD yang menunjukkan bahwa tingkat pemahaman guru terhadap materi IPA masih rendah. Kurangnya pemahaman guru terhadap materi IPA juga dikemukakan oleh Simamora dan Redhana (2007) yang menyatakan bahwa guru-guru yang mengajarkan sains banyak mengalami masalah pembelajaran yang berkaitan dengan model pengubahan konseptual ditinjau dari karakteristik suatu konsep baru.

Pelajaran IPA merupakan salah satu mata pelajaran yang penting ditanamkan pada anak didik karena melalui pembelajaran IPA, siswa mampu bersikap ilmiah dalam memecahkan masalahmasalah yang dihadapi (Rusnadi, 2013). Pembelajaran IPA diharapkan dapat menjadi wahana bagi siswa untuk mempelajari diri sendiri dan alam sekitar, serta prospek pengembangan lebih lanjut. Pembelajaran IPA merupakan suatu proses penyampaian pengetahuan, yang dilaksanakan dengan menuangkan pengetahuan kepada siswa (Khusniati, 2012). Menurut Morrison dan Estes (2007) menyatakan bahwa aplikasi skenario dunia nyata merupakan strategi yang efektif untuk mengajarkan IPA sebagai proses.

Dalam pembelajaran IPA perlu memiliki strategi mengajar yang lebih inovatif agar bidang studi yang dibelajarkan mampu diserap dengan baik. Mata pelajaran IPA adalah salah satu mata pelajaran dasar yang wajib dibelajarkan dengan mengikutsertakan benda-benda lain yang mendukung pembelajaran tersebut (Listyawati, 2013). Proses pembelajaran IPA memadukan berbagai konsep fisika, kimia, biologi, dan bumi antariksa lebih berpotensi untuk mengembangkan pengalaman dan kompetensi siswa memahami alam sekitar (Listiawati, 2012). Dalam menerapkannya di dalam kehidupan sehari-hari (susiani, 2013). Menurut (Trisnani, 2015) pelajaran IPA memiliki peranan penting dalam perkembangan manusia, baik dalam hal perkembangan teknologi yang dipakai untuk menunjang kehidupanya maupun dalam hal penerapan konsep, tanggung jawab, peduli lingkungan, nilai susila, kerja keras, rasa ingin tahu, senang membaca, estetika, nilai ekonomi, kreatif, teliti, skeptis, menghargai prestasi, pantang menyerah, terbuka, jujur, cinta damai, objektif, hemat, percaya diri, 
dan cinta tanah air, tetapi pada kenyataannya pendidikan karakter yang terbangun belum sesuai. Pembelajaran IPA tidak lepas dari media dan bahan ajar yang digunakan. Akan tetapi, media dan bahan ajar yang beredar di lapangan belum sesuai dengan harapan pemerintah. Kaitannya dengan materi IPA terpadu (Puspitoroni, 2014) IPA harus diajarkan dengan pembelajaran yang memungkinkan siswa mengembangkan kemampuan yang dimilikinya dan dapat membangun sendiri konsepnya. Dasar dari pembelajaran tersebut adalah pembelajaran konstruktivisme (Rizal, 2014)

Menurut Laksana (2014) masalahmasalah yang terjadi saat ini antara lain guru menyajikan materi yang tidak sesuai, mempresentasikan penjelasan yang tidak perlu, menjelaskan konsepsi secara prematur, menggunakan istilah-istilah yang membingungkan, kurang menekan pentingnya konteks, mengabaikan pengetahuan awal siswa, sedikit membahas aplikasi konsep dan terlalu banyak menggunakan persamaan matematis.

Penelitian terbaru yang dilakukan oleh Setiawati (2011) memperkuat fakta bahwa memang terjadi miskonsepsi pada calon guru. Hasil penelitiannya menunjukkan terdapat variasi tingkat miskonsepsi pada berbagai konsep IPA (khususnya biologi) dengan persentase miskonsepsi di atas 50\%. Melihat fakta ini, tidak menutup kemungkinan bahwa miskonsepsi yang sama juga terjadi pada guru dan calon guru sekolah dasar.

\section{METODE}

Penelitian ini merupakan penelitian deskriptif kualitatif. Rancangan penelitian kualitatif dapat diwujudkan dengan tahaptahap penelitian kualitatif. Penelitian ini dilakukan melalui tiga tahap, yakni satu tahap pralapangan, tahap ini merupakan tahap penyusunan, perencanaan, dan penyiapan segala bentuk materi yang dibutuhkan sebagai bahan dasar tahap berikutnya. dua tahap lapangan, pada tahap ini dilakukan proses pengumpulan data, peneliti menggunakan alat-alat penelitian yang sudah dipersiapkan sebelumnya. Alat penelitian yang penting digunakan adalah catatan lapangan. Catatan lapangan adalah catatan yang dibuat oleh peneliti pada saat mengadakan pengamatan, pemberian tes diagnostik, dan wawancara. Kemudian, data digolongkan menjadi; data pemahaman konsep, profil miskonsepsi serta penyebab/sumber miskonsepsi yang dialami guru. tiga tahap pasca lapangan adalah melakukan analisis data lanjutan, pengambilan simpulan akhir, konfirmasi dan penyusunan laporan. Kegiatan analisis data lanjutan dilakukan setelah keseluruhan data terkumpul dan setelah kegiatan pengumpulan data di lapangan terakhir.

Penelitian ini dilakukan di Provinsi Bali. Subjek penelitian sebanyak 64 orang calon guru yang berasal dari mahasiswa S1 PGSD Universitas Pendidikan Ganesha, calon guru sudah duduk di semester 8 . Jumlah calon guru laki-laki 20 laki-laki dan 44 orang perempuan.

Analisis data dilakukan secara induktif. Analisis secara induktif dilakukan untuk menemukan simpulan akhir terhadap data yang dikumpulkan sedikit demi sedikit. Analisis yang dilakukan yaitu: satu Jawaban informan pada saat wawancara tentang sumber informasi konsep-konsep IPA yang mereka pelajari. dua Petikan-petikan hasil tes diagnostik dan wawancara.

\section{HASIL DAN PEMBAHASAN}

Sementara itu, dari hasil tes diagnostik dan wawancara pada informan menunjukkan bahwa dalam setiap item tes diagnostik terdapat miskonsepsi. Konsepsi paling rendah adalah pada konsep gerak jatuh bebas dan konsepsi paling tinggi pada konsep gerhana matahari. Sementara konsepsi ilmiah calon guru dengan persentase lebih besar atau sama dengan $50 \%$ adalah konsep zat yang diperlukan dalam proses fotosintesis, konsep zat yang dihasilkan dalam proses fotosintesis, konsep pernafasan pada tumbuhan, konsep air dalam wujud gas, konsep perbedaan berat dan massa, konsep tekanan pada benda cair, konsep kuat arus listrik, konsep rotasi bumi, konsep benda-benda langit yang memancarkan cahayanya sendiri, konsep revolusi bumi, konsep gerhana bulan, konsep gerhana matahari

Untuk lebih jelasnya, profil konsepsi calon guru tentang materi IPA sekolah dasar dapat dilihat pada Tabel 1. 
Tabel 1. Persentase Konsepsi IImiah Calon Guru dalam Materi IPA SD

\begin{tabular}{llc}
\hline No & \multicolumn{1}{c}{ Konsepsi ilmiah } & $\begin{array}{c}\text { Persentase } \\
(\%)\end{array}$ \\
\hline 1. & Konsep zat-zat yang diperlukan dalam proses fotosintesis pada & 53,1 \\
& tumbuhan hijau & \\
2. & Konsep proses fotosintesis membutuhkan cahaya & 25,0 \\
3. & Konsep zat-zat yang dihasilkan dari proses fotosintesis & 84,3 \\
4. & Konsep proses pernafasan pada tumbuhan & 50,0 \\
5. & Konsep tumbuhan hijau mendapatkan makanan dari proses & 56,2 \\
& fotosintesis & 50,0 \\
6. & Konsep air dalam wujud gas & 56,3 \\
7. & Konsep perbedaan berat dan massa suatu benda padat & 25,0 \\
8. & Konsep massa jenis zat & 81,3 \\
9. & Konsep tekanan pada benda cair & 31,3 \\
10. & Konsep pemuaian udara & 34,3 \\
11. & Konsep gaya gesekan & 21,9 \\
12. & Konsep gaya gravitasi di bulan & 50,0 \\
13. & Konsep kuat arus listrik & 3,1 \\
14. & Konsep gerak jatuh bebas & 31,3 \\
15. & Konsep gaya pegas & 90,6 \\
16. & Konsep rotasi bumi & 84,3 \\
17. & Konsep benda-benda langit yang memancarkan cahayanya sendiri & 71,9 \\
18. & Konsep revolusi bumi & 78,1 \\
19. & Konsep gerhana bulan & 93,7 \\
20. & Konsep gerhana matahari & \\
\hline
\end{tabular}

Konsepsi ilmiah calon guru sangat

alternatif atau miskonsepsi yang terjadi. beragam, demikian pula dengan konsep Konsep altenatif ditampilkan dalam Tabel 2.

Tabel 2. Bentuk-bentuk konsep alternatif (miskonsepsi) calon guru dalam materi IPA SD

\begin{tabular}{llc}
\hline \multicolumn{1}{c}{ Konsep ilmiah } & \multicolumn{1}{c}{ Konsep alternatif } & $\%$ \\
\hline $\begin{array}{l}\text { Konsep zat-zat yang } \\
\text { diperlukan dalam proses } \\
\text { fotosintesis pada tumbuhan }\end{array}$ & $\begin{array}{l}\text { Zat yang dibutuhkan dalam proses fotosintesis adalah } \\
\text { air karena air berfungsi untuk melarutkan zat hara }\end{array}$ & \\
dalam tanah & 15,6
\end{tabular}
hijau

Zat yang dibutuhkan dalam proses fotosintesis adalah air karena air dapat mempercepat terjadinya fotosintesis Zat yang dibutuhkan dalam proses fotosintesis adalah air karena air diperlukan untuk mempercepat pertumbuhan dan perkembangan tumbuhan Zat yang dibutuhkan dalam proses fotosintesis adalah uap air karena uap air dapat terjadi dari proses penguapan di bagian daun oleh sinar matahari

Konsep proses fotosintesis membutuhkan cahaya

Konsep zat-zat yang dihasilkan dari proses fotosintesis
Proses fotosintesis tidak dapat terjadi pada malam hari karena fotosintesis hanya dapat terjadi jika terdapat sinar matahari saja

Gas yang dihasilkan dalam jumlah besar oleh tumbuhan hijau ketika ada cahaya matahari adalah karbondioksida karena gas oksigen diperlukan dalam proses tersebut 


\begin{tabular}{l} 
Konsep ilmiah \\
\hline \multicolumn{1}{c}{ Konsep proses pernafasan } \\
pada tumbuhan \\
\\
Konsep tumbuhan hijau \\
mendapatkan makanan dari \\
proses fotosintesis
\end{tabular}

Konsep air dalam wujud gas

Konsep perbedaan berat dan massa suatu benda padat

Konsep massa jenis zat
Gas yang dihasilkan dalam jumlah besar oleh

tumbuhan hijau ketika ada cahaya matahari adalah

karbondioksida karena gas tersebut digunakan dalam

proses pernafasan tumbuhan

Tumbuhan bernafas di siang hari karena tumbuhan

sedang melakukan proses fotosintesis

Tumbuhan bernafas di siang hari karena terdapat

udara seperti karbondioksida di lingkungan sekitarnya

Tumbuhan bernafas di siang hari dengan cara

menghirup karbondioksida, sedangkan pada malam

hari menghirup oksigen

Tumbuhan hijau memperoleh makanan dari zat hara di

dalam tanah kemudian menggunakannya dalam

proses fotosintesis

Tumbuhan hijau memperoleh makanan dari air di dalam tanah karena air adalah sumber makanan untama tumbuhan hijau

$\%$

Gelembung-gelembung yang muncul ketika air mendidih adalah udara yang terdapat di dasar air yang mengalir ke bagian atas permukaan air

Gelembung-gelembung yang muncul ketika air mendidih adalah udara yang yang berasal dari gas

oksigen dan hidrogen di dalam air

Gelembung-gelembung yang muncul ketika air mendidih adalah gas oksigen karena gas tersebut akan menguap ketika air didihkan

Besaran yang dapat diukur dengan menggunakan neraca duduk adalah berat karena memiliki satuan kilogram

Besaran yang dapat diukur dengan menggunakan neraca duduk adalah berat karena massa dengan berat adalah sama

Berdasarkan gambar, dua buah benda yang terbuat dari bahan yang sama tetapi memiliki massa yang berbeda akan ada yang terapung dan tenggelam karena kedua benda tersebut memiliki massa jenis yang berbeda tergantung besar kecilnya suatu benda Berdasarkan gambar, dua buah benda yang terbuat dari bahan yang sama tetapi memiliki massa yang berbeda akan ada yang terapung dan tenggelam karena peristiwa ini dipengaruhi oleh luas penampang dari benda tersebut

Berdasarkan gambar, dua buah benda yang terbuat dari bahan yang sama tetapi memiliki massa yang berbeda akan terapung jika dimasukkan ke dalam air laut karena tempat memepengaruhi terapung atau tidaknya suatu benda Berdasarkan gambar, dua buah benda yang terbuat dari bahan yang sama tetapi memiliki massa yang berbeda akan ada yang terapung dan tenggelam karena kedua buah benda tersebut memiliki tekanan yang berbeda 


\begin{tabular}{|c|c|c|}
\hline \multirow{3}{*}{$\begin{array}{l}\text { Konsep ilmiah } \\
\text { Konsep tekanan pada } \\
\text { benda cair }\end{array}$} & Konsep alternatif & $\%$ \\
\hline & $\begin{array}{l}\text { Berdasarkan gambar, titik yang tekanannya terbesar } \\
\text { adalah titik } \mathrm{P} \text { karena benda yang terdapat paling atas } \\
\text { mendapatkan tekanan yang besar dari zat cair }\end{array}$ & 12,4 \\
\hline & $\begin{array}{l}\text { Berdasarkan gambar, titik yang tekanannya terbesar } \\
\text { adalah titik } \mathrm{P} \text { karena mempunyai luas permukaan yang } \\
\text { lebih besar }\end{array}$ & 6,3 \\
\hline \multirow[t]{2}{*}{ Konsep pemuaian udara } & $\begin{array}{l}\text { Balon-balon udara jika terus bergerak ke atas, lama } \\
\text { kelamaan balon tersebut akan pecah karena tekanan } \\
\text { udara semakin tinggi sehingga terdapat perbedaan } \\
\text { besarnya tekanan udara di dalam balon }\end{array}$ & 15,6 \\
\hline & $\begin{array}{l}\text { Balon-balon udara jika terus bergerak ke atas, lama } \\
\text { kelamaan balon tersebut tidak akan pecah karena } \\
\text { balon tersebut akan menyusut/mengecil dan turun } \\
\text { kembali ke bawah }\end{array}$ & 53,1 \\
\hline Konsep gaya gesekan & $\begin{array}{l}\text { Berdasarkan ilustrasi, benda yang diam tidak } \\
\text { mengalami gaya karena benda yang diam tidak }\end{array}$ & 59,4 \\
\hline
\end{tabular}

Konsep gaya gravitasi di bulan mengalami perpindahan/bergerak

Berdasarkan ilustrasi, suatu benda jika dijatuhkan di permukaan bulan tidak akan terjatuh ke bawah karena di bulan tidak terdapat gaya gravitasi

Berdasarkan ilustrasi, suatu benda jika dijatuhkan di permukaan bulan tidak akan terjatuh ke bawah karena di bulan tidak terdapat udara

Konsep kuat arus listrik Berdasarkan gambar, kuat arus listrik yang masuk ke lampu sama besar dengan kuat arus yang keluar dari lampu karena memiliki rangkaian seri

Berdasarkan gambar, kuat arus listrik setelah keluar dari lampu akan berkurang karena arus listrik sudah digunakan oleh lampu

Berdasarkan gambar, kuat arus listrik setelah keluar dari lampu akan berkurang karena arus listrik terhambat oleh kabel

Konsep gerak jatuh bebas Dua buah bola yang terbuat dari bahan yang berbeda jika dijatuhkan dari ketinggian yang sama maka bola yang lebih berat akan menyentuh lantai terlebih dahulu Konsep gaya pegas Berdasarkan gambar, besarnya gaya tarik yang dimiliki oleh benda (i) lebih besar daripada benda (ii) hal ini disebabkan karena gaya gesekan yang terjadi pada benda (i) lebih besar

Berdasarkan gambar, besarnya gaya tarik yang dimiliki oleh benda (i) lebih besar daripada benda (ii) hal ini disebabkan karena luas penampang benda (i) lebih

Konsep rotasi bumi besar daripada luas penampang benda (ii) Peristiwa matahari terbit di sebelah timur dan tenggelam di sebelah barat terjadi karena gerakan bumi mengelilingi matahari dimana setiap planet berputar mengelilingi pusat tata surya yaitu matahari

Konsep benda-benda langit yang memancarkan Bulan adalah benda langit yang dapat memancarkan cahaya sendiri karena bulan termasuk bintang 


\begin{tabular}{llc}
\hline \multicolumn{1}{c}{ Konsep ilmiah } & \multicolumn{1}{c}{ Konsep alternatif } & $\%$ \\
\hline & $\begin{array}{l}\text { Bulan adalah benda langit yang dapat memancarkan } \\
\text { cahaya sendiri karena bulan termasuk satelit yang } \\
\text { Konsep revolusi bumi }\end{array}$ & 6,3 \\
& $\begin{array}{l}\text { Semua planet di dalam tata surya termasuk bulan } \\
\text { beredar mengelilingi bumi karena adanya peristiwa } \\
\text { revolusi }\end{array}$ & 15,6 \\
& $\begin{array}{l}\text { Semua planet beredar mengelilingi matahari tetapi } \\
\text { bulan hanya beredar mengelilingi bumi }\end{array}$ & 12,5 \\
Konsep gerhana bulan & $\begin{array}{l}\text { Berdasarkan gambar, gerhana matahari terjadi jika } \\
\text { posisi bulan berada diantara bumi dan matahari } \\
\text { Konsep gerhana matahari }\end{array}$ & 21,9 \\
& $\begin{array}{l}\text { Berdasarkan gambar, gerhana matahari terjadi jika } \\
\text { posisi bumi berada diantara bulan dan matahari } \\
\text { (Data Diolah, 2016) }\end{array}$ \\
\hline
\end{tabular}

Selain temuan berupa miskonsepsi yang disajikan pada Tabel 1 tersebut, juga diperoleh hasil penelitian berupa sumber penyebab miskonsepsi calon guru. Berdasarkan hasil tes diagnostik yang memuat 20 buah konsep dalam materi IPA sekolah dasar, terdapat 10 konsep yang paling banyak miskonsepsi pada calon guru. Melalui analisis terhadap hasil wawancara mendalam, maka diperoleh sumber penyebab dari tipe miskonsepsi yang paling banyak terjadi pada calon guru. Sumber miskonsepsi yang paling dominan adalah bersumber dari hasil kontruksi calon guru itu sendiri yaitu $81,6 \%$ dan $18,4 \%$ persepsi calon guru yang menyatakan bahwa bahan ajar sebagai sumber miskonsepsi. Kemudian persepsi calon guru yang menyatakan bahan ajar sebagai penyebab terjadinya miskonsepsi ditelusuri secara faktual dengan menganalisis beberapa bahan ajar yang di dalamnya terdapat miskonsepsi. Analisis ini dilakukan pada dua jenis bahan ajar yang sering digunakan oleh calon guru yaitu bahan ajar jenis LKS dan buku teks yang diterbitkan oleh Depdiknas.

Miskonsepsi-miskonsepsi yang menjadi temuan dalam penelitian ini merupakan gambaran mental yang dibayangkan secara intuitif oleh seseorang atas dasar pengalaman sehari-harinya. Seperti yang dinyatakan Sadia (2001) bahwa, miskonsepsi hanya dapat diterima dalam kasus-kasus tertentu dan tidak berlaku untuk kasus-kasus lainnya serta tidak dapat digeneralisasi. Konsepsi tersebut pada umumnya dibangun dalam upaya memberi makna terhadap dunia pengalaman mereka sehari-hari dan hanya merupakan penjebaran pragmatis terhadap dunia nyata. Miskonsepsi dimungkinkan juga didapat oleh seseorang dari proses pembelajaran sebelumnya dalam tingkatan pendidikan tertentu.

Penemuan miskonsepsi dalam penelitian ini sejalan dengan penjelasan di atas. Meskipun calon guru telah memperoleh mata kuliah yang membahas tentang materi IPA di sekolah dasar sejak pendidikan tinggi, akan tetapi miskonsepsi masih terjadi. Kemungkinan hal ini disebabkan oleh adanya pembatasan konstruksi seperti yang dikemukakan di atas. Selain itu, adanya miskonsepsi juga dapat diakibatkan munculnya pengetahuan baru hasil konstruksi sendiri yang tidak sesuai dengan pengetahuan ilmiah (Suparno, 2005).

Miskonsepsi dalam materi IPA dalam temuan ini sangat beragam. Temuan sebelumnya memperlihatkan bahwa terjadi miskonsepsi pada sebagian besar materi matematika dan IPA (Akbas \& Gencturk, 2011; Hershey, 2004; Howe, 1993; Timur, 2012). Hal ini menandakan bahwa miskonsepsi dapat terjadi pada siswa, calon guru, dan guru.

Melalui penelitian ini juga diperoleh bahwa penyebab miskonsepsi adalah bahan ajar. Berdasarkan hasil penelitian, bahan yang menyebabkan calon guru miskonsepsi adalah buku-buku untuk jenjang sekolah dasar yang pernah calon guru pelajari serta buku LKS yang banyak digunakan di sekolah-sekolah dasar. Temuan ini sejalan dengan penelitian yang dilakukan Yuliati 
(2007). Hasil penelitian tersebut menyatakan penyebab miskonsepsi dapat berasal dari buku yang dimiliki siswa. Suparno (2005) berpendapat bahwa miskonsepsi yang bersumber dari buku teks dapat disebabkan karena bahasanya sulit atau karena penjelasannya yang tidak benar. Selain itu, gambar, diagram, grafik, atau sumber informasi lainnya yang diperoleh dari buku juga dapat menimbulkan miskonsepsi pebelajar. Hasil penelitian Setiawati (2011) juga memperoleh hasil sebesar 3,80\% miskonsepsi calon guru disebabkan oleh buku teks.

\section{SIMPULAN DAN SARAN}

Berdasarkan temuan dari hasil penelitian, maka dapat ditarik simpulan sebagai berikut. (1) Miskonsepsi pada konsep-konsep dalam materi IPA sekolah dasar sangat bervariasi. $\mathrm{Hal}$ ini menunjukkan bahwa calon guru memiliki beragam konsepsi terhadap suatu konsep yang telah dipelajari. Rata-rata miskonsepsi calon guru adalah 44,8\%. Konsep-konsep yang banyak mengalami miskonsepsi, diantaranya yaitu; konsep fotosintesis dapat terjadi pada malam hari sebesar $75 \%$; konsep tumbuhan bernafas di siang hari $50 \%$; konsep air dalam wujud gas $50 \%$; konsep massa jenis suatu benda yang terbuat dari bahan yang sama $75 \%$; konsep pemuaian yang terjadi pada benda gas $59,4 \%$; konsep benda diam mengalami gaya $59,44 \%$; konsep gaya gravitasi pada permukaan bulan 78,1\%; konsep kuat arus listrik 50\%; konsep gerak jatuh bebas 96,9\%; dan konsep besarnya gaya tarik suatu benda 68,8\%. (2) Penyebab miskonsepsi calon guru pada konsepkonsep dalam materi IPA sekolah dasar didominasi oleh diri calon guru sendiri persepsi calon guru yang menyatakan bahwa bahan ajar sebagai sumber miskonsepsi. Hasil analisis bahan ajar seperti LKS dan buku teks menunjukkan beberapa konsep IPA yang terdapat di dalamnya memang mengandung konsep yang miskonsepsi.

\section{DAFTAR PUSTAKA}

Akbas, Y \& Gencturk, E. 2011. The Effect of Conceptual Change Approach to
Eliminate 9th Grade High School Students' Misconceptions about Air Pressure. Educationals Sciences: Theory \& Practice, 2217-2222

Amien. 1990. Pemetaan Konsep: Suatu Tehnik untuk Meningkatkan Belajar yang Bermakna. Mimbar Pendidikan Tahun IX, 55-69.

Cakir, M. 2008. Constructivist Approaches to Learning in Science and Their Implications for Science Pedagogy: A Literature Review. International Journal of Environmental \& Science Education, 3 (4), 193-206

Degeng, I N. S. 2013. IImu pembelajaran: Klasifikasi variable untuk pengembangan teori dan penelitian. Bandung: Aras Media

Fowler dan Jaoude. 1987. Using hierarchichal concept /proposition maps to plan instruction that addresses existing and potential student misunderstanding in science. New York: Cornell University.

Gagne, R.M. 1985. The Condition of Learning and Theory of Instruction. New York: CBS College Publishing.

Hafizah, D., Haris, V., \& Eliswatis. (2014). Analisis Miskonsepsi Siswa Melalui Tes Multiple Choice Menggunakan Certainty of Response Index Pada Mata Pelajaran Fisika Man 1 Bukittinggi. Edusainstika Jurnal Pendidikan MIPA, 1(1), 2005-2008.

Hershey, D. R. 2004. Avoid misconceptions when teaching about plants. Actionbioscience.org.http://www.acti onbioscience.org/education/hershey .html (diakses 31 Oktober 2015)

Howe, A. C. 1993. A Vygotskian Perspective on Teaching for Conceptual Change. In The Proceedings of the Third International Seminar on Misconceptions and Educational Strategies in Science and Mathematics, Misconceptions Trust: Ithaca, New York.

Khusniati, M. (2012). Pendidikan Karakter Melalui Pembelajaran Ipa. Jurnal 
Pendidikan IPA Indonesia, 1(2), 204-210. Retrieved from http://journal.unnes.ac.id/nju/index.p hp/jpii/article/view/2140

Laksana, D.N L. 2014. Profil Pemahaman Konsep IPA Guru-Guru Kelas Sekolah Dasar di Kabupaten Ngada. Jurnal IImiah Pendidikan Citra Bakti, 1 (1), 15-26.

Listyawati , Ni Nym, M. S. D. N. S. (2013, July 3). Pengaruh Model Pembelajaran Kuantum Berbantuan Peta Pikiran Terhadap Kemampuan Berpikir Kritis Siswa Pada Pembelajaran Ipa Kelas V Sd. Mimbar PGSD. Retrieved from http://ejournal.undiksha.ac.id/index.p hp/JJPGSD/article/view/779

Listyawati, M. (2012). Pengembangan Perangkat Pembelajaran Ipa Terpadu Di Smp. Journal of Innovative Science Education, 1(1), 61-69.

Longfield, J. 2009. Discrepant Teaching Events: Using an Inquiry Stance to Address Students' Misconceptions. International Journal of Teaching and Learning in Higher Education, 21 (2), 265-271

Mosik, \& Maulana, P. (2010). Usaha mengurangi terjadinya miskonsepsi fisika melalui pembelajaran dengan pendekatan konflik kognitif. Jurnal Pendidikan Fisika Indonesia, 6, 98103.

Novak. 1987. Proceeding of the second international seminar misconcepsition and educational strategies in Science and Mathematics. New York: Cornell University.

Purnamasari, J., Herpratiwi, H., \& Kandar, S. (2015, January 9). Evaluasi Pembelajaran Ipa Berbasis Pendidikan Karakter. Jurnal Teknologi Informasi Komunikasi Pendidikan. Retrieved from http://jurnal.fkip.unila.ac.id/index.php /JTP/article/view/1551

Puspitorini, R., Prodjosantoso, A. K., Subali,
B., \& Jumadi, J. (2014, October 9). Penggunaan Media Komik Dalam Pembelajaran Ipa Untuk Meningkatkan Motivasi Dan Hasil Belajar Kognitif Dan Afektif. Cakrawala Pendidikan. Retrieved from

http://journal.uny.ac.id/index.php/cp/ article/view/2385.

Putrayasa, I. B. (2013, October 1). Penelusuran Miskonsepsi Dalam Pembelajaran Tata Kalimat Dengan Pendekatan Konstruktivisme Berbasis Inkuiri Pada Siswa Kelas I Smp Laboratorium Undiksha Singaraja. Jurnal Pendidikan Indonesia. Retrieved from http://ejournal.undiksha.ac.id/index.p $\mathrm{hp} / \mathrm{JPI} /$ article/view/2168

Reigeluth, C.M. \& Carr-Cheliman, A.A. 2009. Theories for Different Outcomes of Instruction. Dalam C.M. Reigeluth, \& A.A. Carr-Cheliman (Eds.), Instructional-Design Theories and Models: Building a Common Knowledge Base, Vol. 3 (hal. 195197), New York: Routledge.

Rezky Agung, H., \& Tri Edi, M. S. (2014). Analisis Kesalahan dan Miskonsepsi Siswa Kelas VIII Pada Materi Aljabar. Jurnal IImu Pendidikan Dan Pengajaran, 1(2), 173-184.

Rizal. (2014). Pengaruh pembelajaran inkuiri terbimbing dengan mind map terhadap keterampilan proses sains dan hasil belajar IPA. Jurnal Pendidikan Sains, 2(4), 159-165. Retrieved from http://journal.um.ac.id/index.php/jps

Rusnadi, D. P. P. N. W. A. (2013, July 5). Penerapan Model Pembelajaran Kooperatif Tipe Team Games Tournament Untuk Meningkatkan Kemampuan Berpikir Kritis Dan Hasil Belajar Ipa. MIMBAR PGSD. Retrieved from http://ejournal.undiksha.ac.id/index.p hp/JJPGSD/article/view/881

Sadia, I W. 2001. Pengembangan Buku Ajar IPA Pendidikan Dasar Berwawasan Sains-Teknologi-Masyarakat (Studi 
Pembelajaran IPA Menuju Siswa Yang Literasi Sains dan Teknologi). Laporan Penelitian (tidak diterbitkan). Singaraja: STKIP Singaraja.

Seraphin, K.D., Philippoff, J., Kaupp, L. \& Vallin, L.M. 2012. Metacognition as means to increase the effectiveness of inquiry-based science education. Science Education International, 23 (4), 366-382

Setiawati, G.A.D. 2011. Kajian Miskonsepsi dalam Materi Fotosintesis dan Respirasi Tumbuhan pada Mahasiswa Jurusan Pendidikan Biologi Universitas Pendidikan Ganesha Tahun Pelajaran 2010/2011. Tesis (tidak diterbitkan). Singaraja: Universitas Pendidikan Ganesha.

Suparno, P. 2005. Miskonsepsi dan Perubahan Konsep dalam Pendidikan Fisika. Jakarta: PT Grasindo.

Suparno, Paul. 2005. Miskonsepsi dan Perubahan Konsep Pendidikan Fisika. Jakarta: Grasindo

Suryanto. 1997. Pemahaman guru Sekolah Dasar (SD) terhadap Konsep konsep IImu Pengetahuan Alam (IPA): Suatu diagnosis adanya miskonsepsi. Laporan Penelitian (Tidak diterbitkan) Jakarta: Pusat Penelitian Universitas Terbuka.

Susiani, K., Dantes, N., \& Tika, N. (2013, May 10). Pengaruh Model Pembelajaran Quantum Terhadap Kecerdasan Sosio-Emosional Dan
Prestasi Belajar Ipa Siswa Kelas V Sd Di Banyuning. Jurnal Pendidikan Dasar. Retrieved from http://119.252.161.254/ejournal/index.php/jurnal_pendas/arti cle/view/525

Taufiq, M. (2012). Remediasi Miskonsepsi Mahasiswa Calon Guru Fisika Pada Konsep Gaya Melalui Penerapan Model Siklus Belajar (Learning Cycle) 5E. Jurnal Pendidikan IPA Indonesia (Indonesian Journal of Science Education), 1(2), 198-203. https://doi.org/10.15294/jpii.v1i2.213 9

Timur, S. 2012. Preschool Teachers Concerning the Subject "Force and Motion". Educationals Sciences: Theory \& Practice, 3038-3049

Trisnani, I., Hasyim, A., \& Djasmi, S. (2015, January 12). Evaluasi Program Pembelajaran Ipa. Jurnal Teknologi Informasi Komunikasi Pendidikan. Retrieved from http://jurnal.fkip.unila.ac.id/index.php /JTP/article/view/4778

Yuliati, L. 2007. Miskonsepsi dan Remediasi Pembelajaran IPA. Buku Ajar. Jakarta: Universitas Terbuka 